\title{
The Effect of Knee Tuck Jump Plyometrics Training on Dollyo Chagi Athlete Taekwondo
}

\author{
Fakhruddin, AR. Shadiqin, Tri Irianto \\ Department of Sport Education and Health \\ Lambung Mangkurat University \\ Banjarmasin, Indonesia \\ frarizqa@gmail.com
}

\begin{abstract}
This study aims to figure out the effect of plyometrics knee tuck jump exercise towards dollyo chagi kick speed of junior taekwondo athletes. The method of this study is pre-experiment design. The sample is 12 junior taekwondo athletes at Banjarbaru, Indonesia. Instrument or measuring instrument used for the speed of the Dolly Chagi kick, both at the initial test and at the final test used a stopwatch and sand sack / hogu. Data analysis using the Hypothesis Test (average comparison analysis) Paired Samples Test (SPSS 21). The results show that on pre-test dollyo chagi kick speed of junior taekwondo athletes at Banjarbaru City is at the average 19,75 times with standard deviation $=2,094$. On post-test dollyo chagi kick on junior taekwondo athletes at Banjarbaru City is at the average 22,25 time with standard deviation 1,485 . Whereas tcount $=6,966>\operatorname{ttabel}(11 ; 0,025)=2,201$ or with sig. (2-tailed) $=0,000$, it is found out that sig. $(2$-tailed $)=0.000$ $<0.05$ so tcount is significant. The conclusion is that there is an effect of plyometrics knee tuck jump exercise towards dollyo chagi kick speed of junior taekwondo athletes.
\end{abstract}

Keywords: effect, plyometrics, knee tuck jump, speed, dollyo chagi, kick taekwondo

\section{INTRODUCTION}

In taekwondo martial arts, there are several types of kicks, such as the Dolly Chagi kick, which is around foot kick with the body sideways position. This kick is often used by taekwondo athletes during a match which relies on the jolt of the knee to the side using a pincushion. Observations during training and at the 2015 Banjarbaru Taekwondo Championship, there were still many junior athletes whose kicks were not on target and lacked explosive power. Thus, strength and speed training, especially in the leg muscles, is still lacking in direction, resulting in junior taekwondo athletes when kicking does not have the good power of the leg muscle explosion. According to Bompa [1], explosion power or power is the result of two power capabilities and maximum speed with a short amount of time. Based on the opinion above shows that a taekwondo athlete who has good strength and speed and with regular training the athlete will have an increase in muscle power or good power.

This condition occurs, among others, due to the low ability of the trainer to make the training program still ignored, even training to train strength and speed has never been done so that it will have an impact on the results of a kick that will be done by an athlete, according to Harsono's opinion [2] Planning of training programs must be carried out in a well-organized, methodical and scientific manner so that trainers can help athletes, especially those who are gifted to achieve the highest achievements. The trainer's knowledge in training also influences in conducting an exercise program, as a trainer must be able to train properly and correctly, be able to apply good and appropriate training methods and materials in order to obtain optimal results. Besides the supporting factors of training such as training facilities and targets also influence in increasing athlete achievement. When we return to the dollyo chagi kicking movement, many factors play a role in the dollyo chagi kicking movements such as leg muscle power, abdominal muscle strength, back muscle strength, balance and flexibility. This is in accordance with the opinions expressed Riadi [3] "Components of physical conditions include: strength, endurance, explosive muscle power, speed, flexibility, agility, coordination, balance, accuracy and reaction ".

Training given properly and correctly in accordance with the training program provided will be able to increase the strength and speed of kicks, the training can be done with plyometrics (knee tuck jump) as Radcliffe \& Farentinos [4] stated: "Plyometrics training is an exercise that has a special characteristic, namely a very strong muscle contraction that is a response to dynamic loading or rapid strain of the muscles involved". Based on the opinion above shows that knee tuck jump plyometrics training is a form of exercise that can increase the explosive (explosive power) of leg muscles that will lead of course to the speed of the Dolly Chagi kick. The plyometrics knee tuck jump exercise pattern mostly follows the power chain concept, which mostly involves the hip and leg muscles, which will continue to kick speed. Therefore the greater the power the faster the kick. The characteristics of the plyometrics training method will certainly have an impact on changes in the ability of the muscles of the lower limbs, and will also affect the ability to kick especially more specifically in the speed of the Dolly Chagi kick. Thus the general objective to be achieved in this study is to determine the quality of Dolly Chagi kicks in junior taekwondo athletes.

\section{MethodOLOGY}

The research method used is an experimental method. Basic the use of this method is an experimental activity that begins by giving treatment to subjects which end with a test to determine the effect of the treatment that has been given. The research design uses the one-group pretest-posttest design, which means that a group of subjects is subject to treatment for a certain period of time, whereas measurements are taken before and after treatment is given, and the effect of treatment is measured from the difference between the initial measurement (T1) and final measurement (T2) [5]. The sample was 12 junior taekwondo athletes in Banjarbaru, South of Kalimantan, Indonesia. In order to ascertain the 
presence or absence of the influence of knee tuck jump plyometric exercises on the speed of the dolly chagi kick, the knee tuck jumps plyometric exercises as the independent variable, and the dollyo chagi kick speed as the dependent variable. Then, the data were analysed by t-test. Instrument or measuring instrument used for the speed of the Dolly Chagi kick, both at the initial test and at the final test used a stopwatch and sand sack/hogu [6].

\section{RESULTS AND DISCUSSION}

The results of the analysis of this study prove that there is a significant influence of plyometrics knee tuck jump training on the speed of dollyo chagi kicks in junior Taekwondo athletes in Banjarbaru City significantly ( $p$ $<0.05)$. This is evidenced by tcount $=6,966$ > ttable $(11$; $0,025)=2,201$, or with Sig. (2-tailed) $=0,000$; it turns out that Sig. (2-tailed) $=0,000<\alpha=0.05$; thus, the tcount is significant and the hypothesis proposed in this study is proven true. The results of the initial test data and the final test of the speed of the Dolly Chagi kick in junior Taekwondo athletes in Banjarbaru City. In the initial test data, the speed of Dolly Chagi kicks in junior Taekwondo athletes in Banjarbaru City obtained an average of 19.75 times, with the highest Dolly Chagi kick speed of 23 times and the lowest Dolly Chagi kick speed of 16 times. Whereas in the final test data the speed of Dolly Chagi kicks in junior Taekwondo athletes in Banjarbaru City obtained an average of 22.25 times, with the highest speed of Dolly Chagi kicks 25 times and the lowest speed of Dolly Chagi kicks 20 times. So that it can be seen from the average initial test of the Dolly Chagi kick speed on the junior Taekwondo athletes in Banjarbaru City obtained an average of 19.75 times, while the final test of the Dolly Chagi kick speed on the junior Taekwondo athlete of the Banjarbaru City obtained an average of 22.25 times, of the two averages there is a difference of 2.5 times, meaning that after being treated for 6 weeks with a frequency of 3 times a week there is a significant increase.

Dolo Chagi kick is a circular foot kick forward with a sideways body position. The kick is often used by taekwondo athletes during a match where the kick relies on the knees to the side using a padded foot (baldeung). A taekwondo athlete to be able to kick fast and strong certainly requires regular training so that the athlete can have an increase especially in explosive power or good leg muscle power. This is very necessary because leg muscle power is the main element in producing kick speed. As stated by Radcliffe \& Farentinos [4], the knee tuck jump exercise is "Exercise that develops speed and power for leg and hip muscles, especially the flexor muscles of the hips and thighs, gastrocnemius, gluteal, quadriceps and hamstrings, at high speeds full of energy". This theory is the basis of this research, in which this exercise can increase leg muscle explosive power.

The knee tuck jump plyometrics exercise is an exercise that is done quickly and strongly the exercise of the knee tuck jump exercise begins with standing upright and place both palms facing down at chest level. Then start the movement with a quarter-squat position and then jump up quickly. Movement is done by bending both legs forward toward the chest and when the movement jumps up, try to knees touching the palms. Perform movement continuously and repeatedly. The knee tuck jump plyometric exercise can be used as an exercise to increase leg muscle explosive power. The advantages of knee tuck jump training include: Knee tuck jump training can increase speed and strength so that the movement can produce good leg muscle power. From knee tuck jump training that leads to the branch of taekwondo, this exercise can improve the ability to kick so as to produce good kick power as well.

According to Chu and Myer [7] "for resistance training to be focused on increasing power, the lifts must be made more dynamic in nature. A form of squatting known as the jump squat is an example of this type of exercise. In this type of exercise, the athlete uses a load of approximately 30 to 60 percent of $1 \mathrm{RM}$ ". "It means that for training against the burden towards increasing explosive power, the force must be dynamic and natural. Squat as a squat exercise while jumping. In this type of exercise, the athlete uses a training load of approximately $30-60 \%$ of 1 maximum repetition (1 RM) ". In this study the treatment was given to the sample using a training load of $30-60 \%$ of 1 maximum repetition (RM) performed with a form of plyometric knee tuck jump training with its application as follows: on the first week applying intensity of $30 \%, 35 \%, 40 \%$, on the second week applying the intensity of $35 \%, 40 \%, 45 \%$, on the third week applying the intensity of $40 \%, 45 \%, 50 \%$, on the fourth week applying the intensity of $45 \%, 50 \%, 55 \%$, on the fifth week applying intensity of $50 \%, 55 \%, 60 \%$, in the sixth week applying 55\%, 50\%, 45\%, with this the researcher applies the intensity of maximum repetition (RM) with an increase of $5 \%$ at each meeting, but at the initial meeting each week a $5 \%$ decrease in intensity, so that adaptation occurs in the muscles of junior taekwondo athletes in Banjarbaru City.

According to the opinion expressed by Radcliffe \& Farentinos [4] "This knee tuck jump exercise performs a series of fast, explosive jumps and the muscles developed in this exercise are hip and thigh flexors, gastrocnemius, gluteal, quadriceps and hamstrings ". In this exercise the set is 2-4 sets, the number of repetitions is 10-20 times and rest periods are 1-2 minutes between sets. The researcher uses the above opinion on the application of sets and rest periods and their application as follows: in the first week to the fifth week applying 2 sets, 3 sets, 4 sets, in the sixth week applies 3 sets, 2 sets, 2 sets, in this study applying set with an increase of 1 set for each meeting and a decrease in sets after the application of maximum intensity at the fifth-week meeting, on the sixth week there is a decrease in the set in order for adaptation to the muscles of the junior taekwondo athlete of Banjarbaru City and so that no muscle fatigue at the time of carrying out the test the end so that the results are more leverage.

The results of the study showed that an increase between the initial test and the final test after being given plyometric knee tuck jump training for 6 weeks, 18 meetings with a frequency of 3 meetings a week, could increase the speed of the dollyo chagi kick in junior Taekwondo athletes in Banjarbaru City. So that this exercise can be utilized in increasing kick speed in Taekwondo athletes by applying the correct training program procedures, so that athletes do not experience overtraining.

In this study there are some limitations faced during the course of the study are as follows: First, this study only discusses one variable that is related to the speed of Dolly Chagi kicks that is plyometrics knee tuck jump training, whereas there are many more variables that play a role in increasing the speed of Dolly Chagi kicks. Both of these 


\section{ACKNOWLEDGMENT}

studies did not have a control group so the implications of the results of the study were used among limited groups. Third, before doing sample training, I still did not understand the knee tuck jump plyometric exercise, so the researcher gave an explanation and example of the movement, then the sample was given the opportunity to try to understand and be able to perform the movement well. The fourth place for training is also often moved because Gor Rudy Resnawan who is usually used for training, is used by the manager for other activities. The five overall research samples are students so that the training schedule is bumped into school and tutoring schedules. Therefore, the training schedule is adjusted to the tutoring schedule so that the training is held on Monday, Thursday, and Saturday.

\section{CONCLUSION}

The conclusion of this study is based on data analysis, hypothesis testing and discussion that has been done in the previous chapter, that there is an effect of knee tuck jump plyometric exercises on the speed of dollyo chagi kicks in junior Taekwondo athletes in Banjarbaru City.
We would like to be grateful to the Dean of Teacher Training and Education Faculty, Lambung Mangkurat University, who has supported us in the form of funding. Therefore we could join this International Conference.

\section{REFERENCES}

[1] T. O. Bompa, Periodization Theory and Methodology of Training: Canada Human Kinetics, 2009.

[2] H. Harsono, Latihan Kondisi Fisik, Tasikmalaya: PJKR FKIP UNSIL, 2001

[3] M. Riadi, Raih Kebugaran melalui latihan beban (Weight Training): Mataram, 2010.

[4] C. James, Radcliffe and F. C. Robert, Plaiometrik: Untuk Meningkatkan Power. Surakarta: Program Studi Ilmu Keolahragaan, 2002.

[5] S. Sugiyono, Metode penelitian Kombinasi (mixed methods). Bandung: Alfabeta, 2014.

[6] J. Lubis, Pencak Silat Peanduan Praktis. Jakarta: PT Raja Grafindo Persada, 2004.

[7] D. A. Chu, and G. C. Myer, Plyometrics. United States of America: Human Kinetics, 2013. 